\title{
A new combination in Gynochthodes (Rubiaceae)
}

\author{
W.W. Seah \\ Singapore Botanic Gardens, National Parks Board, \\ 1 Cluny Road, 259569 Singapore \\ seahweiwei@gmail.com
}

\begin{abstract}
Morinda scortechinii (King \& Gamble) Ridl. was recently placed in the synonymy of Gynochthodes umbellata (L.) Razafim. \& B.Bremer. However, the two taxa were found to differ in a number of leaf and flowering head characters and hence should be considered distinct species. A new combination Gynochthodes scortechinii (King \& Gamble) W.W.Seah is necessary owing to recent changes in the circumscription of several genera in the Morindeae tribe.
\end{abstract}

Keywords. Gynochthodes umbellata, Gynochthodes scortechinii, Morinda, new combination, Peninsular Malaysia

\section{Introduction}

The genus Gynochthodes Blume (Rubiaceae) was recently expanded following molecular phylogenetic studies. This new circumscription of the genus has led to the inclusion of many taxa with a lianescent or climbing habit that were earlier placed in Morinda L. (Razafimandimbison et al., 2008, 2009; Razafimandimbison \& Bremer, 2011). Many new combinations have already been made to effect the transfer of the respective taxa from Morinda to Gynochthodes (Razafimandimbison \& Bremer, 2011; Wong \& Razafimandimbison, 2015). This included Morinda umbellata L., now known as Gynochthodes umbellata (L.) Razafim. \& B.Bremer, which was investigated as part of a study on the genus for the Flora of Singapore project.

Razafimandimbison \& Bremer (2011) included Morinda scortechinii (King \& Gamble) Ridl. in the synonymy of Gynochthodes umbellata. However, after comparing the type specimens of the two taxa, available on JSTOR® Global Plants (https://plants. jstor.org/), I discovered that they differ greatly in a number of leaf and flowering head characters (Table 1) and therefore should be considered distinct species. A new combination is necessary as Morinda scortechinii belongs in Gynochthodes along with all other climbing species previously placed in Morinda. 
Table 1. Comparison of Gynochthodes scortechinii (King \& Gamble) W.W.Seah to Gynochthodes umbellata (L.) Razafim. \& B.Bremer. All measurements are made from dried specimens of the respective species as found in Singapore and Peninsular Malaysia.

\begin{tabular}{|c|c|c|}
\hline Character & Gynochthodes scortechinii & Gynochthodes umbellata \\
\hline Twig indumentum & $\begin{array}{l}\text { Densely covered in golden } \\
\text { brown hairs }\end{array}$ & More or less glabrous \\
\hline Leaf indumentum & $\begin{array}{l}\text { Upper surface with evenly } \\
\text { scattered golden brown hairs and } \\
\text { lower surface covered in golden } \\
\text { brown hairs }\end{array}$ & More or less glabrous \\
\hline Leaf dimensions & $\begin{array}{l}(4.7-) 6.8-8.1 \times(1.8-) 2.4-3.8 \\
\mathrm{~cm}\end{array}$ & $\begin{array}{l}(3.7-) 4.9-12.5 \times(1.0-) 1.5- \\
3.8 \mathrm{~cm}\end{array}$ \\
\hline Leaf shape & Broadly elliptic to obovate & Elliptic \\
\hline $\begin{array}{l}\text { Leaf secondary } \\
\text { veins }\end{array}$ & $8-12$ pairs & 5-7 pairs \\
\hline Leaf tertiary veins & Loosely reticulate & Minutely reticulate \\
\hline $\begin{array}{l}\text { Flowering head } \\
\text { peduncle } \\
\text { indumentum }\end{array}$ & $\begin{array}{l}\text { Densely covered in golden } \\
\text { brown hairs }\end{array}$ & More or less glabrous \\
\hline $\begin{array}{l}\text { Fruiting head } \\
\text { indumentum }\end{array}$ & $\begin{array}{l}\text { Sparsely covered in golden } \\
\text { brown hairs }\end{array}$ & More or less glabrous \\
\hline
\end{tabular}

\section{Taxonomy}

Gynochthodes scortechinii (King \& Gamble) W.W.Seah, comb. nov.

Morinda umbellata L. var. scortechinii King \& Gamble, J. Asiat. Soc. Bengal, Pt. 2, Nat. Hist. 73: 88 (1904). - Morinda scortechinii (King \& Gamble) Ridl., Fl. Malay Penins. 2: 122 (1923). - TYPE: Peninsular Malaysia, Perak, Goping, May 1885, Scortechini 2015 (lectotype CAL [CAL0000024839] (fl), designated here; isolectotypes K [K000763801, K000763802] (fl)).

Distribution and habitat. The species is most likely endemic to Peninsular Malaysia as it has so far only been collected once from Perak (type locality) and again in Pahang. Although Ridley (1923) stated "Distrib. Siam." no specimens have been found from there. It has been reported from a "gently sloping narrow ridge between two bukit over sandstone in primary forest" (Everett FRI 14387). However, the distribution and habitat details remain poorly known. 
Provisional IUCN conservation assessment. The species is represented by two specimens from two localities within Peninsular Malaysia collected close to 85 years apart. Given the long duration between collections, it is difficult to determine if the species still persists today without an effort to verify its occurrence in the field. Therefore, it is assessed as Data Deficient (DD) (IUCN, 2012).

Additional specimens examined. PENINSULAR MALAYSIA: Pahang: Taman Negara, alt 285 m, 9 Jul 1970, Everett FRI 14387 (K, KEP n.v., SING [SING0269650]) (fr).

Notes. The species differs from Gynochthodes umbellata in its indumentum of golden brown hairs on all parts of the plant, leaves with more pairs of secondary veins (8-12 pairs) and loosely reticulate tertiary venation as well as flowering heads borne on densely tomentose peduncles. In comparison, Gynochthodes umbellata is more or less glabrous on all parts of the plant and has leaves with fewer pairs of secondary veins (5-7 pairs) and minutely reticulate tertiary venation, as well as flowering heads borne on more or less glabrous peduncles. For further distinctions between the two species, see Table 1. Within the genus Morinda, the species was previously treated as distinct from $M$. umbellata (= Gynochthodes umbellata), in taxonomic works such as Wong (1984, 1989), and Turner (1997 ['1995’]).

ACKNOWLEDGEMENTS. This work was conducted as part of the Gynochthodes treatment for the Flora of Singapore. I thank the staff at the Singapore Botanic Gardens Herbarium and Herbarium at the Royal Botanic Gardens Kew for their assistance. I am also grateful to Dr P.V. Prasanna, Mr A. Kumar, Mr A. Bhattacharjee, and Mr S. Sachan at the Central National Herbarium, Botanical Survey of India, for conveying an image of the type specimen. Dr Alex Yee Thiam Koon, Dr Wong Khoon Meng, and Dr Carmen Puglisi are acknowledged for their valuable advice. The editor and reviewers are thanked for their helpful feedback.

\section{References}

IUCN (2012). IUCN Red List Categories and Criteria: Version 3.1, $2^{\text {nd }}$ ed. Switzerland, Gland and UK, Cambridge: IUCN.

Razafimandimbison, S.G. \& Bremer, B. (2011). Nomenclatural changes and taxonomic notes in the tribe Morindeae (Rubiaceae). Adansonia 33(2): 283-309.

Razafimandimbison, S.G., Rydin, C. \& Bremer, B. (2008). Evolution and trends in the Psychotrieae alliance (Rubiaceae) - A rarely reported evolutionary change of manyseeded carpels from one-seeded carpels. Molec. Phylogen. Evol. 48: 207-223.

Razafimandimbison, S.G., McDowell, T.D., Halford, D.A. \& Bremer, B. (2009). Molecular phylogenetics and generic assessment in the tribe Morindeae (Rubiaceae-Rubioideae): How to circumscribe Morinda L. to be monophyletic? Molec. Phylogen. Evol. 52: 879886.

Ridley, H.N. (1923). Morinda L. In: The Flora of the Malay Peninsula, vol. 2-Gamopetalae, pp. 117-119. London: L. Reeve \& Co., Ltd.

Turner, I.M. (1997 ['1995’]). A Catalogue of the Vascular Plants of Malaya. Gard. Bull. Singapore 47: 1-757. 